\title{
Microbial and enzymatic activity of soil contaminated with azoxystrobin
}

\author{
Małgorzata Baćmaga • Jan Kucharski • \\ Jadwiga Wyszkowska
}

Received: 23 April 2015 / Accepted: 24 August 2015 / Published online: 7 September 2015

(C) The Author(s) 2015. This article is published with open access at Springerlink.com

\begin{abstract}
The use of fungicides in crop protection still effectively eliminates fungal pathogens of plants. However, fungicides may dissipate to various elements of the environment and cause irreversible changes. Considering this problem, the aim of the presented study was to evaluate changes in soil biological activity in response to contamination with azoxystrobin. The study was carried out in the laboratory on samples of sandy loam with a $\mathrm{pH}$ of 7.0 in $1 \mathrm{Mol} \mathrm{KCl} \mathrm{dm}^{-3}$. Soil samples were treated with azoxystrobin in one of four doses: 0.075 (dose recommended by the manufacturer), 2.250, 11.25 and $22.50 \mathrm{mg} \mathrm{kg}^{-1}$ soil DM (dry matter of soil). The control soil sample did not contain fungicide. Bacteria were identified based on 16S rRNA gene sequencing, and fungi were identified by internal transcribed spacer (ITS) region sequencing. The study revealed that increased doses of azoxystrobin inhibited the growth of organotrophic bacteria, actinomycetes and fungi. The fungicide also caused changes in microbial biodiversity. The lowest values of the colony development (CD) index were recorded for fungi and the ecophysiological (EP) index for organotrophic bacteria. Azoxystrobin had an inhibitory effect on the activity of dehydrogenases, catalase, urease, acid phosphatase and alkaline phosphatase. Dehydrogenases were found
\end{abstract}

M. Baćmaga · J. Kucharski · J. Wyszkowska $(\bowtie)$ University of Warmia and Mazury in Olsztyn, Plac Łódzki 3, 10-727 Olsztyn, Poland

e-mail: jadwiga.wyszkowska@uwm.edu.pl to be most resistant to the effects of the fungicide, while alkaline phosphatase in the soil recovered the balance in the shortest time. Four species of bacteria from the genus Bacillus and two species of fungi from the genus Aphanoascus were isolated from the soil contaminated with the highest dose of azoxystrobin $\left(22.50 \mathrm{mg} \mathrm{kg}^{-1}\right)$.

Keywords Azoxystrobin · Microorganisms .

Biodiversity $\cdot$ Enzymes $\cdot$ Resistance $\cdot$ Identification of microorganisms

\section{Introduction}

Pesticides are chemicals which play a major role in maintaining adequate quality of agricultural products by controlling plant pathogens. In addition, they are used in human and animal hygiene, in the protection of feed, food, natural raw materials and products made of them (Chatterjee et al. 2013). Primarily, the use of pesticides is aimed at controlling target organisms. Despite this fact, it is not possible to predict the environmental fate of pesticides. The widespread use, toxicity, mobility and persistence of pesticides may lead to their dissipation to all elements of the natural environment. Thus, the excessive use of pesticides is still a major problem affecting the quality of the natural environment, which is why more and more studies are being conducted to determine their effects on living organisms (Seiber and Kleinschmidt 2011; 
Wyszkowska and Kucharski 2004). The highest quantities of pesticides are accumulated in soil, which may cause changes in the terrestrial environment, often manifested by decreasing soil fertility. Studies on the presence of pesticides in soil and their impact on soil organisms are necessary because soil is most affected by contamination. Microbial activity of soil is used to assess the potential changes caused by these chemicals. Microbial response to contaminants dissipating to soil is prompt and thus can provide necessary information on environmental changes (Zhang et al. 2006). Due to the fact that plant protection products are potentially harmful to non-target organisms, there has been considerable interest in determining their impact on soil microorganisms and processes (Bending et al. 2007).

Azoxystrobin (methyl(E)-2-\{2-[6-(2cyanophenoxy)pyrimidin-4-yloxy]phenyl $\}-3$ methoxyacrylate), a strobilurin-derived fungicide, is one of the most popular chemicals used for the control of fungal plant pathogens. It has a broad spectrum of systemic activity against pathogens by inhibiting mitochondrial respiration in the process of binding with cytochrome $\mathrm{b}$ complexes. The binding process blocks electron transport from cytochrome $\mathrm{b}$ to $\mathrm{c}$, thus inhibiting the generation of energy through the oxidative phosphorylation necessary for cell growth, and finally causes the death of the pathogen (Bartlett et al. 2002). In the natural environment, azoxystrobin is degraded to azoxystrobin acid, which is much more water-soluble and prone to leaching in soils than its parent compound (Ghosh and Singh 2009). Rodrigues et al. (2013) reported that the half-life of azoxystrobin can range from 14 days to 6 months, depending on the microbiological and biochemical soil parameters. Microbial degradation of azoxystrobin is associated with the hydrolysis of the carboxylic ester bond in the parent compound (Katagi 2006). Therefore, microorganisms and enzymes have a significant role in the degradation of this active substance (Clinton et al. 2011).

The literature (Guo et al. 2015) provides limited information on the impact of azoxystrobin on microbial and biochemical activity in different types of soil. Considering this fact, the aim of our study was to determine the effect of azoxystrobin on the soil ecosystem by determining microbial counts, their biodiversity, enzymatic activity of soil, soil resistance and the soil resilience index. In the study, new microbial strains resistant to azoxystrobin were isolated.

\section{Materials and methods}

Soil

A laboratory experiment was carried out on samples of soil with the granulometric composition of sandy loam with a $\mathrm{pH}$ 7.0. The soils were classified as Eutric Cambisols based on the World Reference Base of Soil Resources (2014). The tested soils are characterized in Table 1. Soil samples were collected from the humus level at a depth of 0 to $20 \mathrm{~cm}$, in Tomaszkowo near Olsztyn in north-eastern Poland. The physicochemical properties of the soil was determined by the following methods: grain-size composition of the soil with laser method using a Mastersizer 2000 (PB 33 ed.303.12.2012, 2012), soil pH by potentiometry in aqueous $\mathrm{KCl}$ solution of the concentra-

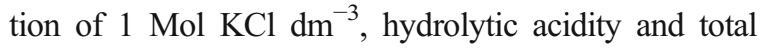
exchangeable bases by the Kappen's method (Carter 1993), content of organic carbon - with Tiurin's method (Nelson and Sommers 1996), content of total nitrogen according to the method by Kjeldahl (PB 29 ed.303.12.2012, 2012), as well as the content potassium, sodium, calcium and magnesium cations by flame photometry (BS EN ISO 11260, 2011).

Fungicide

Azoxystrobin, which is the active ingredient to fungicide Amistar $250 \mathrm{SC}$, was tested in amount of

Table 1 General characteristics of experimental soil

\begin{tabular}{|c|c|}
\hline Parameter & Sandy loam \\
\hline Sand $(2000-50 \mu \mathrm{m}) \%$ & 69.41 \\
\hline Silt $(50-2 \mu \mathrm{m}) \%$ & 27.71 \\
\hline Clay $(<2 \mu \mathrm{m}) \%$ & 2.88 \\
\hline $\mathrm{pH}_{\mathrm{KCl}}$ & 7.00 \\
\hline $\mathrm{HAC}\left(\mathrm{mMol}^{(+)} \mathrm{kg}^{-1}\right)$ & 6.40 \\
\hline TEB $\left(\mathrm{mMol}^{(+)} \mathrm{kg}^{-1}\right)$ & 165.9 \\
\hline $\mathrm{C}_{\text {org }}\left(\mathrm{g} \mathrm{kg}^{-1}\right)$ & 14.30 \\
\hline $\mathrm{N}_{\text {total }}\left(\mathrm{g} \mathrm{kg}^{-1}\right)$ & 0.98 \\
\hline \multicolumn{2}{|c|}{ Exchangeable cations $\left(\mathrm{mg} \mathrm{kg}^{-1}\right)$} \\
\hline $\mathrm{K}^{+}$ & 180.0 \\
\hline $\mathrm{Ca}^{2+}$ & 2571.4 \\
\hline $\mathrm{Na}^{+}$ & 20.0 \\
\hline $\mathrm{Mg}^{2+}$ & 59.5 \\
\hline
\end{tabular}

$\overline{H A C}$ hydrolytic acidity, TEB total exchangeable bases, $C_{\text {org }}$ organic carbon content, $N_{\text {total }}$ total nitrogen content 
$250 \mathrm{~g} \mathrm{dm}^{-3}$. Azoxystrobin belongs to the group of strobilurins, which is designed against fungal diseases in agricultural crops and vegetables. This formulation made by Syngenta in an amount of from 0.8 to $1.0 \mathrm{dm}^{3} \mathrm{ha}^{-1}$. The predicted environmental concentrations (PEC) of azoxystrobin in soil on days 30, 60 and 90 are described in Table 2.

\section{Experimental design}

A laboratory experiment was performed in three replications, in $150 \mathrm{~cm}^{3}$ glass beakers each containing $100 \mathrm{~g}$ of air-dry soil. Before the experiment, soil was passed through a sieve with $2 \mathrm{~mm}$ mesh size. Each sample was treated with a single azoxystrobin as water emulsion in the following doses: 0.075 (dose recommended by the manufacturer), 2.250, 11.250, and $22.500 \mathrm{mg} \mathrm{kg}^{-1}$ soil DM. The control treatment comprised soil without fungicide. The soil was then combined with fungicide and brought to $50 \%$ capillary capacity with the use of deionized water. Beakers were covered with perforated foil and incubated at $25^{\circ} \mathrm{C}$ for 30,60 and 90 days.

\section{Soil microorganisms}

The counts organotrophic bacteria were determined in the Bunt and Rovira medium with the addition of soil extract (Alexander 1973), actinomycetes - in the Küster and Williams medium with the addition of antibiotics nystatin and actidione (Parkinson et al. 1971), and fungi grown on the Martin's medium (1950) with added rose bengal and aureomycin. Plates were kept at $28{ }^{\circ} \mathrm{C}$ throughout the incubation period. Counts of colony forming units (cfu) were determined using a colony counter.

The azoxystrobin effect on the structure and biodiversity of organotrophic bacteria, actinomycetes and fungi was determined in soil samples. Diluted soil

Table 2 Predicted environmental concentrations (PEC) azoxystrobin in soil, $\mathrm{mg} \mathrm{kg}^{-1}$

\begin{tabular}{llll}
\hline Dose of azoxystrobin $\left(\mathrm{mg} \mathrm{kg}^{-1}\right)$ & \multicolumn{3}{l}{ Soil incubation time, days } \\
\cline { 2 - 4 } & 30 & 60 & 90 \\
\hline 0.075 & 0.0049 & 0.0038 & 0.0029 \\
2.250 & 0.1465 & 0.1146 & 0.0896 \\
11.50 & 0.7330 & 0.5731 & 0.4481 \\
22.50 & 1.4660 & 1.1462 & 0.8961 \\
\hline
\end{tabular}

suspensions were incubated in Petri dishes, at $28{ }^{\circ} \mathrm{C}$, in nine replications. Colonies were counted over a period of successive 10 days. Then calculated the colony development index $C D=\left[\mathrm{N}_{1} / 1+\mathrm{N}_{2} / 2+\mathrm{N}_{3} / 3 \ldots . . \mathrm{N}_{10} /\right.$ 10] $\cdot 100$, were $N_{1}, N_{2}, N_{3}, \ldots . N_{10}$ counts of colonies that emerged on day $1,2,3, \ldots, 10$ (Sarathchandra et al. 1997), and the ecophysiological index EP $=-\sum$ (pi $\cdot \log$ pi), were as follows: pi, counts of colonies that emerged on a given day divided by total counts of colonies (De Leij et al. 1993).

\section{Soil enzymes}

Dehydrogenases (EC 1.1) activity, according to the method described by Öhlinger (1996), catalase (EC 1.11.1.6) and urease (EC 3.5.1.5) activity, according to the method by Alef and Nanipieri (1998) and acid phosphatase (EC 3.1.3.2) and alkaline phosphatase (EC 3.1.3.1), according to the method described by Alef et al. (1998), were determined in soil samples in nine replicates. Except for catalase, soil enzymatic activity was measured on a Perkin-Elmer Lambda 25 spectrophotometer (MA, USA) at $\lambda=485 \mathrm{~nm}$ (dehydrogenases) and $\lambda=410 \mathrm{~nm}$ (urease, acid phosphatase and alkaline phosphatase). The activity of catalase was determined based on the decomposition of hydrogen peroxide by potassium permanganate. The following substrates were used to determine enzymatic activity: 2,3,5-triphenyltetrazolium chloride for dehydrogenases (P.P.H Stanlab Sp.J, Poland), $\mathrm{H}_{2} \mathrm{O}_{2}$ for catalase $\mathrm{H}_{2} \mathrm{O}_{2}$ (P.P.H Stanlab Sp.J, Poland), urea for urease (Eurochem BGD Sp. z.o.o, Poland) and 4-nitrophenyl phosphate disodium for acid phosphatase and alkaline phosphatase (ApliChem GmbH, Germany). Enzymatic activity was expressed in the following units per $\mathrm{kg} \mathrm{DM}$ $\mathrm{h}^{-1}$ : $\mu \mathrm{Mol}$ TPF for dehydrogenases, Mol $\mathrm{O}_{2}$ for cata-

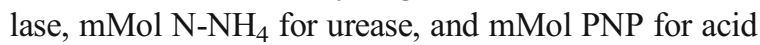
phosphatase and alkaline phosphatase.

Formulas proposed by Orwin and Wardle (2004) were used to determine the soil resistance index (RS) on days 30, 60 and 90, and the soil resilience (RL) index, indicating recovery of balance, on day 90 after contamination with azoxystrobin:

$\operatorname{RS}\left(\mathrm{t}_{0}\right)=1-\frac{2\left|\mathrm{D}_{0}\right|}{\left(\mathrm{C}_{0}+\left|\mathrm{D}_{0}\right|\right)}$

where: $\mathrm{C}_{0}$ is the parameter value under natural conditions over time $t_{0} ; P_{0}$ is the parameter value for soil 
disturbed over time $\mathrm{t}_{0}, \mathrm{D}_{0}=\mathrm{C}_{0}-\mathrm{P}_{0}$.

$R L$ at $t_{x}=\frac{2\left|D_{0}\right|}{\left(\left|D_{0}\right|+|D \times|\right)}-1$

where: $\mathrm{D}_{0}=\mathrm{C}_{0}-\mathrm{P}_{0}, \mathrm{D}_{\mathrm{x}}=\mathrm{C}_{\mathrm{x}}-\mathrm{P}_{\mathrm{x}}, \mathrm{C}_{0}$ is the parameter value under natural conditions over time $t_{0}, P_{0}$ is the parameter value for soil disturbed over time $t_{0}, C_{x}$ is the parameter value under natural conditions over time $t_{x}$, $P_{x}$ is the parameter value for soil disturbed over time $t_{x}$.

Isolation of DNA from bacteria and fungi and their identification

On day 90 of the experiment, bacteria and fungi were isolated from the soil free from fungicide, and samples were treated with either a $0.075 \mathrm{mg} \mathrm{kg}^{-1}$ (dose recommended by the manufacturer) or $22.50 \mathrm{mg} \mathrm{kg}^{-1}$ dose of azoxystrobin. Bacteria were isolated using PCA culture media (distilled water, $1 \mathrm{dm}^{3}$; casein enzymatic hydrolysate, $5 \mathrm{~g}$; yeast extract, $2.5 \mathrm{~g}$; glucose, $1 \mathrm{~g}$; agar, $15 \mathrm{~g}$ ), and fungi were cultured on Sabouraud medium with chloramphenicol (distilled water, $1 \mathrm{dm}^{3}$; yeast extract, $2 \mathrm{~g}$; peptone, $3 \mathrm{~g}$; peptone SP, $3 \mathrm{~g}$; peptone $\mathrm{K}, 3 \mathrm{~g}$; glucose, $19 \mathrm{~g}$; dipotassium hydrogen phosphate, $0.5 \mathrm{~g}$; potassium dihydrogen phosphate, $0.5 \mathrm{~g}$; chloramphenicol, $0.5 \mathrm{~g}$; agar, $15 \mathrm{~g}$ ). Culture media containing an appropriate dilution of soil material $\left(10^{-5}\right.$ for bacteria and $10^{-3}$ for fungi) were incubated under aerobic conditions at $37{ }^{\circ} \mathrm{C}$ for $24-48 \mathrm{~h}$. Characteristic colonies formed by the isolated microorganisms were passaged 10 times to obtain a pure culture. Genomic DNA was isolated using a Bead-Beat Micro Gravity kit (A\&A Biotechnology, Poland), in line with the manufacturer's instructions. Next, the isolated genomic DNA was separated electrophoretically in $1 \%$ agarose gel $\left(5 \mathrm{~mm}^{3}\right.$ samples in gel). A PCR assay was carried out on a 50$\mathrm{mm}^{3}$ sample, using a reaction mixture containing $\mathrm{mm}^{3}$ $(\sim 50 \mathrm{ng})$ of genomic DNA from a sample, $25 \mathrm{~mm}^{3} 2 \times$ PCR Master Mix Plus High GC (A\&A Biotechnology), $0.2 \mathrm{~mm}^{3}$ of each primer, concentration $100 \mu \mathrm{M}$, and $19.6 \mathrm{~mm}^{3}$ sterile water. Conditions of the PCR assay on isolated DNA templates are presented in Table 3. The 16S rRNA gene sequence from bacterial DNA was amplified using a pair of primers: B-all For: GAG TTT GAT CCT GGC TCA G and B-all Rev.: ACG GCT ACC TTA CGA CTT, and the ITS region sequence from fungi was amplified using ITS1: TTC GTA GGT GAA CCT GCG G and ITS4: TCC TCC
GCT TAT TGA TAT GC. PCR products were separated in $2 \%$ agarose gel $\left(2 \mathrm{~mm}^{3}\right.$ samples in gel). DNA fragments obtained by amplification were purified using a Clean-Up AXE kit (A\&A Biotechnology, Poland). PCR products were suspended in $10 \mathrm{mM}$ Tris- $\mathrm{HCl}$ buffer, $\mathrm{pH} 8.0$, diluted to a concentration of $100 \mathrm{ng} \mathrm{mm}^{-3}$ and sent to Macrogen (Netherlands) for sequencing. Identified sequences of $16 \mathrm{~S}$ rRNA gene and ITS region were compared with sequences available in the GenBank database (National Center of Biotechnology Information) using Basic Local Alignment Search Tool (BLAST) analysis.

Statistical analysis

Results were analysed statistically using the Statistica 10.0 package (Statsoft Inc. 2011). Homogeneous groups were identified using Tukey's range test at a significance level of $p=0.01$ by the analysis of variance (ANOVA). The soil microbial counts were estimated using Ward's cluster analysis (CA). The phylogenetic tree of identified microbial strains was prepared in the MEGA 6.0 application by the "neighbour-joining" method. Resistance of soil (RS) to contamination with azoxystrobin was explained by principal component analysis (PCA). In addition, Pearson's linear coefficients of correlation between the dose of azoxystrobin and the analysed parameters were calculated. The percentage of observed variance in microbial counts and enzymatic activity were calculated by two-way ANOVA using the $\eta^{2}$ coefficient.

\section{Results and discussion}

Soil microorganisms

Microorganisms play a key role in soil biochemical processes but can also affect the health of plants through interactions (Oliveira et al. 2009). However, microbial activity can be distorted by various types of contaminants dissipating into the terrestrial environment, such as fungicides and other substances. Changes in microbial activity can be manifested by their lower count and biodiversity, which has a strong impact on maintaining correct soil quality (Saha et al. 2012). According to Kucharski and Wyszkowska (2008), pesticides can have varying effects on the growth and development of microorganisms, and their impact is not only determined 
Table 3 Conditions of the PCR assay on isolated DNA templates

\begin{tabular}{|c|c|c|c|c|c|c|}
\hline \multirow[t]{2}{*}{ Reaction steps } & \multicolumn{2}{|c|}{ Temperature } & \multicolumn{2}{|l|}{ Time } & \multicolumn{2}{|c|}{ Number of cycles } \\
\hline & Bacteria & Fungi & Bacteria & Fungi & Bacteria & Fungi \\
\hline Initial denaturation & $94{ }^{\circ} \mathrm{C}$ & $94{ }^{\circ} \mathrm{C}$ & $2 \min$ & $2 \min$ & 1 & 1 \\
\hline Denaturation & $\begin{array}{l}94{ }^{\circ} \mathrm{C} \\
58{ }^{\circ} \mathrm{C}\end{array}$ & $\begin{array}{l}94^{\circ} \mathrm{C} \\
58^{\circ} \mathrm{C}\end{array}$ & $\begin{array}{l}30 \\
45 s\end{array}$ & 30 & 30 & 30 \\
\hline Elongation & $72{ }^{\circ} \mathrm{C}$ & $72{ }^{\circ} \mathrm{C}$ & $1: 30 \mathrm{~min}$ & $1 \mathrm{~min}$ & & \\
\hline Final elongation & $72{ }^{\circ} \mathrm{C}$ & $72{ }^{\circ} \mathrm{C}$ & $5 \mathrm{~min}$ & $5 \mathrm{~min}$ & 1 & 1 \\
\hline
\end{tabular}

by the type and application rate but also depends on microorganisms dwelling in the soil ecosystem. Findings from studies show that azoxystrobin changes the counts of organotrophic bacteria, actinomycetes and fungi (Table 4). Microbial counts significantly correlated with the dose of azoxystrobin (the percentage of variance ranged from 8.4 to $45.7 \%$ ) and soil incubation time (the percentage of variance ranged from 10.9 to $61.2 \%$ ). A significant decrease in the counts of fungi was observed after treatment of soil with azoxystrobin. The strongest effect was observed for the highest dose (22.50 $\mathrm{mg} \mathrm{kg}^{-1}$ ), which reduced the fungi counts on day 30 by $0.294 \log$, on day 60 by $0.397 \log$ and on day 90 by $0.426 \mathrm{log}$. A study by Crouzet et al. (2010) revealed decreased counts of fungi in soil treated with mesotrione (herbicide). Walia et al. (2014) reported that mancozeb (fungicide) applied to soil in doses of between 10 and $2000 \mathrm{mg} \mathrm{kg}^{-1}$ had a strong inhibitory effect on fungi. Similar findings, but after the treatment of soil with herbicides, were made by Baćmaga et al. (2015), who tested a mixture of diflufenican + mesosulfuron-methyl + iodosulfuron-methyl-sodium, and Araújo et al. (2003), who tested the effects of glyphosate. On the other hand, Martinez et al. (2008) found no significant differences in fungal counts in soil contaminated with sulfentrazone. The effects of azoxystrobin on the counts of oligotrophic bacteria and actinomycetes were variable. On day 30 of the experiment, a stimulating effect of azoxystrobin on these microorganisms was found. The highest count of organotrophic bacteria was recorded for dose $22.50 \mathrm{mg} \mathrm{kg}^{-1}$ (increase by $0.200 \mathrm{log}$ ) and of actinomycetes for dose $0.075 \mathrm{mg} \mathrm{kg}^{-1}$ (increase by $0.215 \log$ ). On days 60 and 90, azoxystrobin inhibited the growth of organotrophic bacteria and actinomycetes, as indicated by negative values of correlation coefficients. The microbial counts decreased in proportion to the dose of the applied fungicide. Reduction in the counts of bacteria and actinomycetes after treatment

Table 4 Microorganisms counts in soil contaminated with azoxystrobin, $\log \mathrm{CFU} \mathrm{kg}{ }^{-1}$ soil DM

\begin{tabular}{|c|c|c|c|c|c|c|c|c|c|}
\hline \multirow{3}{*}{$\begin{array}{l}\text { Dose of azoxystrobin } \\
\left(\mathrm{mg} \mathrm{kg}^{-1}\right)\end{array}$} & \multicolumn{3}{|c|}{ Organotrophic bacteria } & \multicolumn{3}{|c|}{ Actinomycetes } & \multicolumn{3}{|l|}{ Fungi } \\
\hline & \multicolumn{9}{|c|}{ Soil incubation time, days } \\
\hline & 30 & 60 & 90 & 30 & 60 & 90 & 30 & 60 & 90 \\
\hline 0.000 & $10.186^{\mathrm{b}}$ & $10.474^{\mathrm{a}}$ & $10.459^{\mathrm{a}}$ & $9.938^{\mathrm{c}}$ & $10.288^{\mathrm{a}}$ & $10.293^{\mathrm{a}}$ & $7.153^{\mathrm{abc}}$ & $7.348^{\mathrm{ab}}$ & $7.440^{\mathrm{a}}$ \\
\hline 0.075 & $10.294^{\mathrm{ab}}$ & $10.420^{\mathrm{ab}}$ & $10.425^{\mathrm{ab}}$ & $10.153^{\mathrm{ab}}$ & $10.199^{\mathrm{ab}}$ & $10.232^{\mathrm{ab}}$ & $7.112^{\mathrm{abc}}$ & $7.26^{\mathrm{abc}}$ & $7.285^{\mathrm{abc}}$ \\
\hline 2.250 & $10.315^{\mathrm{ab}}$ & $10.311^{\mathrm{ab}}$ & $10.428^{\mathrm{ab}}$ & $10.087^{\mathrm{bcd}}$ & $10.190^{\mathrm{ab}}$ & $10.217^{\mathrm{ab}}$ & $6.878^{\mathrm{bc}}$ & $7.128^{\mathrm{abc}}$ & $7.203^{\mathrm{abc}}$ \\
\hline 11.25 & $10.384^{\mathrm{ab}}$ & $10.270^{\mathrm{ab}}$ & $10.395^{\mathrm{ab}}$ & $9.992^{\mathrm{cd}}$ & $10.168^{\mathrm{cd}}$ & $10.206^{\mathrm{ab}}$ & $6.894^{\mathrm{bc}}$ & $7.073^{\mathrm{abc}}$ & $7.112^{\mathrm{abc}}$ \\
\hline 22.50 & $10.406^{\mathrm{ab}}$ & $10.192^{\mathrm{b}}$ & $10.282^{\mathrm{ab}}$ & $9.941^{\mathrm{c}}$ & $10.137^{\mathrm{abc}}$ & $10.175^{\mathrm{ab}}$ & $6.858^{\mathrm{bc}}$ & $6.951^{\mathrm{bc}}$ & $7.014^{\mathrm{abc}}$ \\
\hline $\bar{x}$ & 10.320 & 10.340 & 10.400 & 10.020 & 10.200 & 10.230 & 7.000 & 7.170 & 7.220 \\
\hline$r$ & 0.813 & $-0.891^{*}$ & $-0.963^{*}$ & -0.547 & -0.762 & -0.791 & -0.709 & $-0.902 *$ & $-0.876^{*}$ \\
\hline
\end{tabular}

Homogeneous groups are denoted with the same letters within microbial groups for all dates of analysis, in columns

$\bar{x}$ mean, $r$ coefficient of correlation at $* p=0.01$

$*^{*} p=0.01$ 
with herbicides were also found by Baćmaga et al. (2014b) in soil contaminated with metazachlor and by Baćmaga et al. (2015) after soil treatment with a mixture of diflufenican + mesosulfuron-methyl + iodosulfuronmethyl-sodium. Similar findings were made by Sebiomo et al. (2011) and Kucharski and Wyszkowska (2008). The study by Sebiomo et al. (2011) analysed the influence of atrazine, primextar, paraquat and glyphosate on soil microorganisms, while Kucharski and Wyszkowska (2008) investigated the effects of Apyros 75 WG containing sulfosulfuron as an active substance. Walia et al. (2014) observed a harmful effect of mancozeb (fungicide) on the populations of actinomycetes caused by all doses ( 10 to $2000 \mathrm{mg} \mathrm{kg}^{-1}$ ), while bacteria were susceptible to treatment with fungicide at the highest doses (1000 and $2000 \mathrm{mg} \mathrm{kg}^{-1}$ ). Increases in actinomycetes counts in response to increasing doses of herbicides were reported by Araújo et al. (2003) in a study with glyphosate, and Tomkiel et al. (2014), who treated soil with a mixture of pethoxamid and terbuthylazine (Successor T $550 \mathrm{SE}$ ). These different effects of pesticides on soil microorganisms may result from the different chemical structures of the active substance or the tolerability of microorganisms to these products. Pesticides, for some microorganisms, may be a suitable nutrient or source of energy, but may be toxic to others and cause disorders in cell metabolism (Crouzet et al. 2010; Singh and Goshal 2010). The response of the tested microorganisms to soil contamination with azoxystrobin was confirmed by Ward's cluster analysis (Fig. 1). Two clusters were identified on the dendrogram. The first cluster comprised organotrophic bacteria and actinomycetes, and the second comprised fungi. It can be concluded from the dendrogram that organotrophic bacteria and actinomycetes responded in a similar manner to the treatment of soil with azoxystrobin.

Pesticides affect soil microbial counts but can also lead to changes in microbial biodiversity (Demenaou et al. 2004; Ratcliff et al. 2006). In our study, the microbial biodiversity was determined based on the colony development (CD) index and the ecophysiological (EP) index. CD values indicated that azoxystrobin had a significant effect on the biodiversity of the tested soil microorganisms (Fig. 2). The highest mean values of the $\mathrm{CD}$ index were found for organotrophic bacteria (59.762) and the lowest for fungi (28.160). With respect to the soil incubation time, the colony development index for organotrophic bacteria and actinomycetes was the highest on day 90 (mean 69.979 for organotrophic bacteria and 37.259 for actinomycetes). The CD index for moulds was the highest on day 30 of the experiment (mean 28.695). Treatment of soil with azoxystrobin at a dose of $22.50 \mathrm{mg} \mathrm{kg}^{-1}$ increased CD values for organotrophic bacteria on days 30 and 60 (by $14.98 \%$ on day 30 , and by $29.11 \%$ on day 60 ). The CD index for actinomycetes increased on all test dates, particularly on day 30 (by $8.31 \%$ ). Fungi were found to be very susceptible to high doses of azoxystrobin. A significant decrease in the $\mathrm{CD}$ index vs. control soil samples was observed on days 30 and 90 following the application of fungicide at a dose of $22.50 \mathrm{mg} \mathrm{kg}^{-1}$ (decrease by 25.0 and $26.97 \%$, respectively). Azoxystrobin also caused changes in the EP index for
Fig. 1 Similar response of microorganisms in soil contaminated with azoxystrobin. Explanation: $B_{\text {org }}$ organotrophic bacteria; Act actinomycetes; Fun fungi; 30,60 and 90 microorganisms counts at 30,60 and 90 days of incubation soil

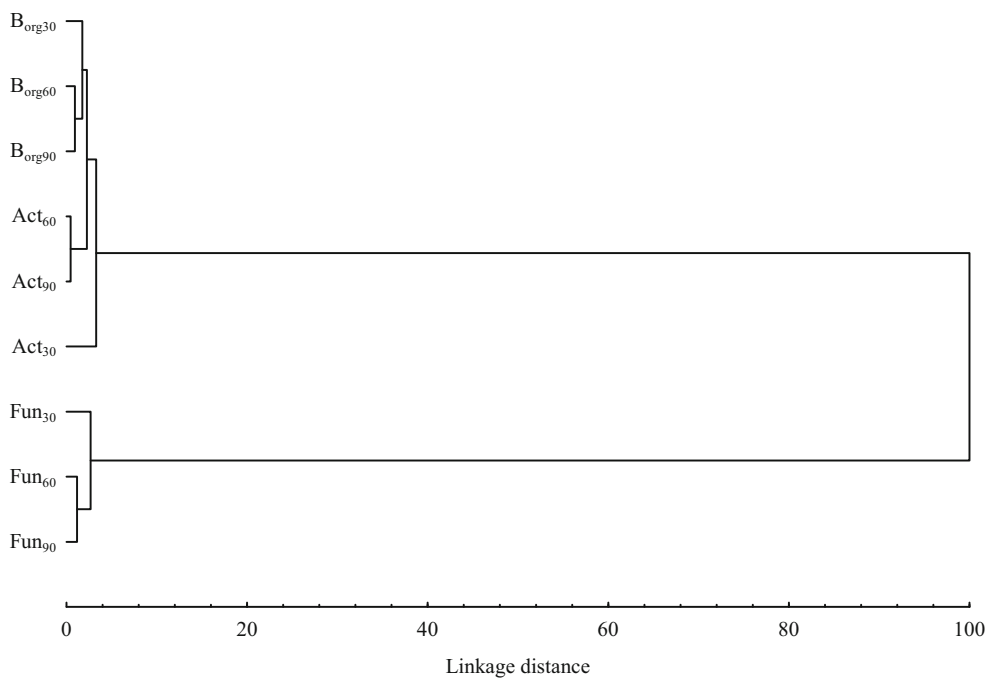


a

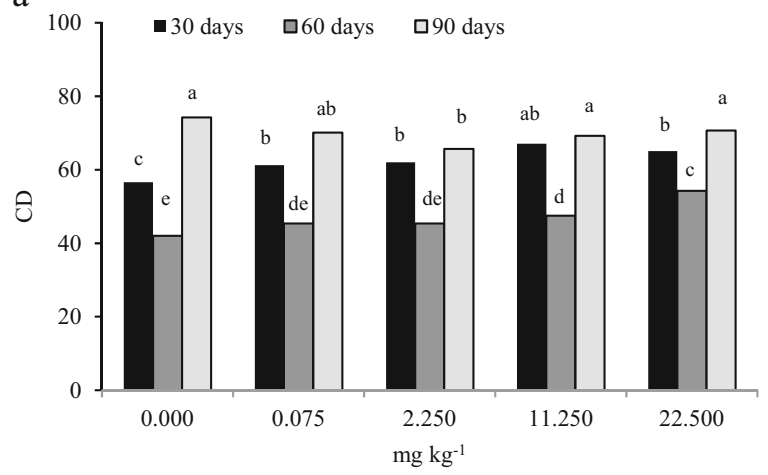

b

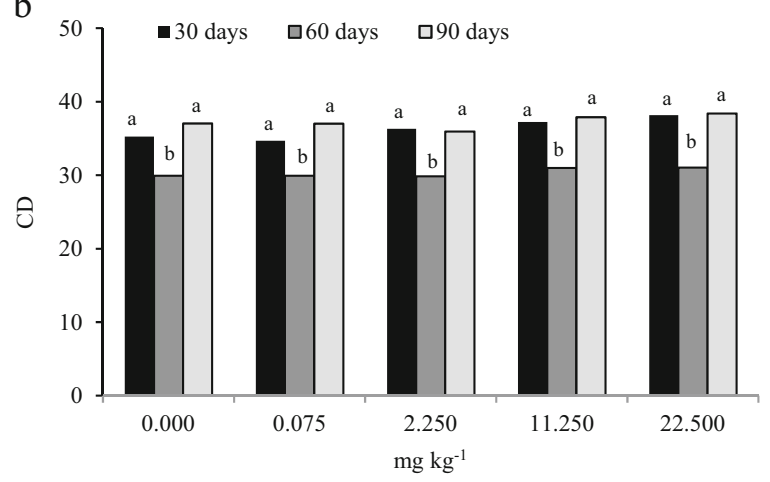

c

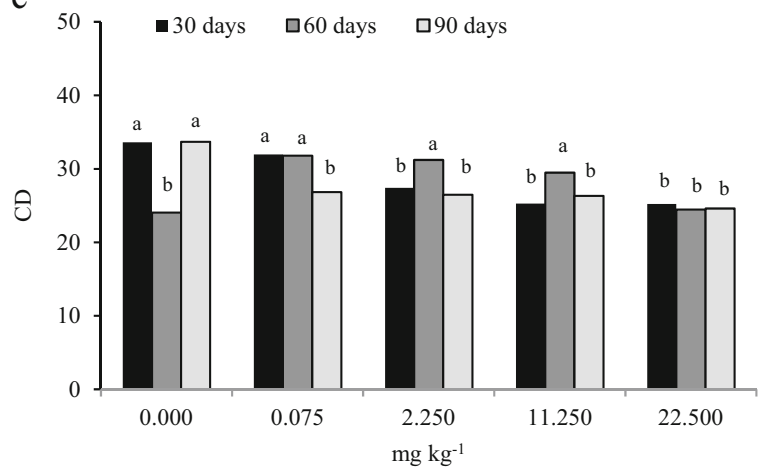

Fig. 2 The effect of azoxystrobin on development index (CD) of a organotrophic bacteria, $\mathbf{b}$ actinomycetes, $\mathbf{c}$ fungi. Explanation: Homogeneous groups are denoted with the same letters within microbial groups for all dates of analysis

microorganisms (Fig. 3). The lowest EP index for microorganisms was found on day 90 (0.533 for organotrophic bacteria, 0.644 for actinomycetes and 0.576 for moulds). Azoxystrobin at the highest dose $\left(22.50 \mathrm{mg} \mathrm{kg}^{-1}\right)$ caused a significant decrease in the EP index on all test dates. The only exception was organotrophic bacteria on day 90 , for which an increase in the EP index by $8.16 \%$ vs. control was found. Generally, soil microorganisms respond promptly to environmental changes and are therefore considered
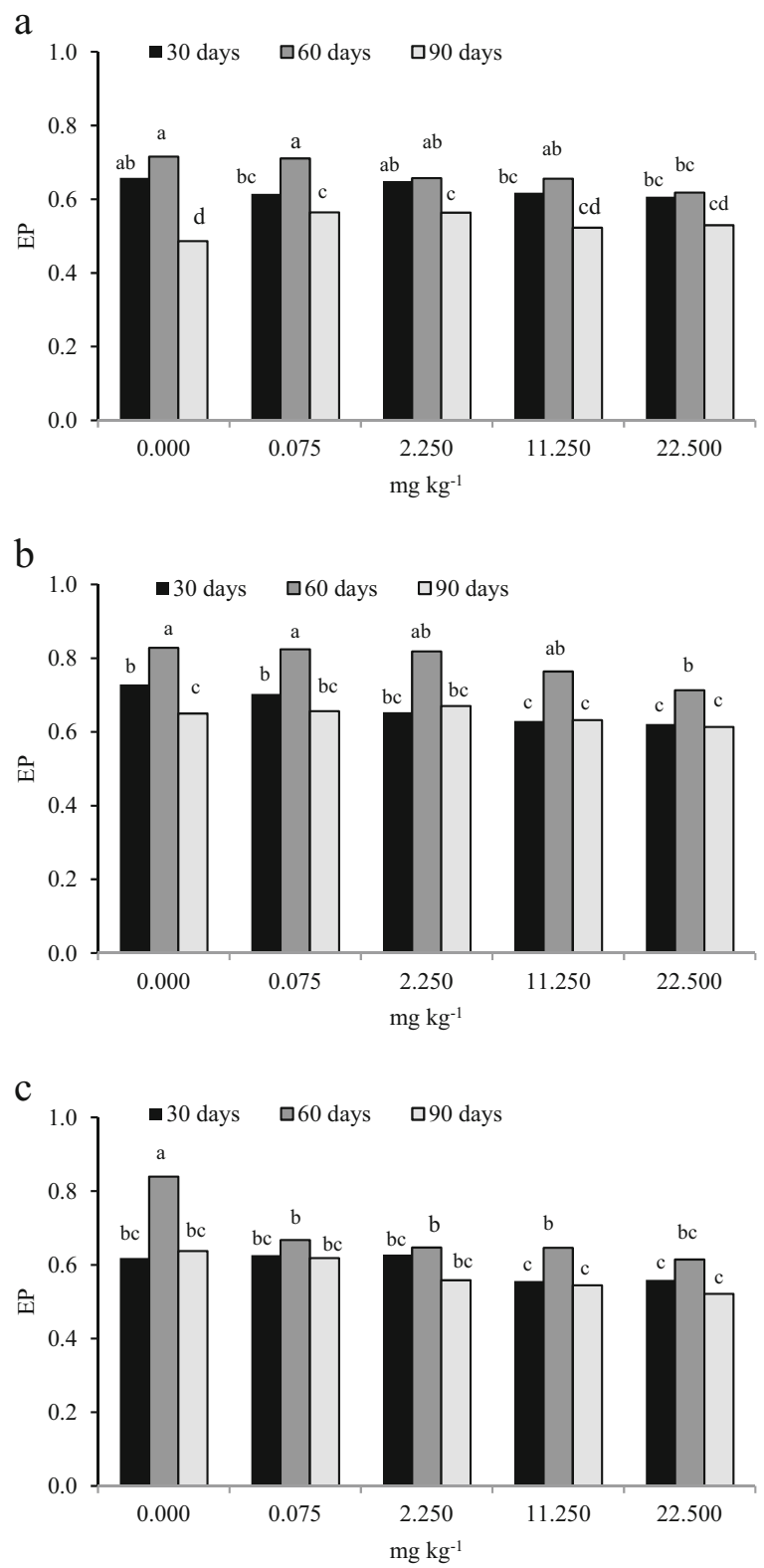

Fig. 3 The effect of azoxystrobin on ecophysiological index (EP) of $\mathbf{a}$ organotrophic bacteria, $\mathbf{b}$ actinomycetes, $\mathbf{c}$ fungi. Explanation: Homogeneous groups are denoted with the same letters within microbial groups for all dates of analysis

robust indicators of soil quality and fertility (Serrano et al. 2009). Modifications in microbial composition manifested by changes in the proportion of r-strategists to K-strategists are caused by pesticides dissipating to the soil and are often used in tests evaluating the impact of pesticides on microbial soil parameters. Sarathchandra et al. (1997) reported that an increase in the $\mathrm{CD}$ index indicates the predominance of fast- 
growing microbes (r-strategists) over slowly-growing ones (K-strategists). On the other hand, a decrease in the EP index may indicate the elimination of microbial species susceptible to stressors, including pesticides, by more resistant ones (De Leij et al. 1993). In our study, the values of the CD and EP indices in contaminated soil were generally lower in comparison to the control sample. These values differed depending on the dose of azoxystrobin, soil incubation time and the group of analysed soil microorganisms. Similar findings were made in a study by Ros et al. (2006) investigating the effects of atrazine.

\section{Soil enzymes}

Enzymatic soil activity is one of the key parameters used in assessing the quality and fertility of soil contaminated with pesticides and other chemicals (Baćmaga et al. 2012; Kucharski et al. 2009; Singh and Kumar 2008; Wyszkowska 2002; Zhang et al. 2014). Pesticides can also have a direct impact on enzymes by inhibiting their catalytic potential, or by the involvement in the modification of microbial activity (Floch et al. 2011). Azoxystrobin inhibits the enzymatic activity of soil, as indicated by negative correlation coefficients between doses and the activity levels of these enzymes (Table 5). Fungicide dose determined from $0.6 \%$ (alkaline phosphatase) to $82.4 \%$ (acid phosphatase) of changes in enzymatic activity, and soil incubation time determined from $3.7 \%$ (catalase) to $99.0 \%$ (alkaline phosphatase) of changes. The most significant changes in enzymatic activity were caused by the highest dose (22.50 $\mathrm{m} \mathrm{kg}^{-1}$ ), which significantly reduced the mean activity of dehydrogenases (by $7.04 \%$ ), catalase (by $22.86 \%$ ), urease (by $31.25 \%$ ), acid phosphatase (by $20.45 \%$ ) and alkaline phosphatase (by $11.78 \%$ ). Literature data suggest that dehydrogenases (Baćmaga et al. 2012; Baćmaga et al. 2014b; Baćmaga et al. 2015; Demenaou et al. 2004; Kucharski and Wyszkowska 2008; Monkiedje et al. 2002), $\beta$-glucosidase (Demenaou et al. 2004; Monkiedje et al. 2002) and alkaline phosphatase (Monkiedje et al. 2002) are the most susceptible to pesticides. Moreover, Chen et al. (2001) demonstrated that benomyl and captan (fungicides) had the strongest inhibitory effect on the activity of dehydrogenases and acid phosphatase. In our study, azoxystrobin had the weakest effect on the activity of dehydrogenases, and the strongest negative effect on urease in the treated soil. Studies by Tomkiel et al.
(2014) showed that a mixture of two herbicides, terbuthylazine and pethoxamid, also inhibited the activity of urease. A similar response of urease was observed by Sukul (2006) after treating soil with metalaxyl (fungicide). Jastrzębska and Kucharski (2007), in an experiment with fungicides (cyprodinil and a mixture of dimoxystrobin + epoxiconazole), noted the negative effects of these pesticides on the activity of dehydrogenases and urease. In our study, the activity of catalase, acid phosphatase and alkaline phosphatase also decreased under the influence of high doses of azoxystrobin, but the effect was less pronounced than that observed for urease. Baćmaga et al. (2014b) found metazachlor (herbicide) to be a potent inhibitor of catalase, acid phosphatase, alkaline phosphatase, arylsulfatase and $\beta$-glucosidase. Wyszkowska and Kucharski (2004) investigated the effects of Triflurotox 250 EC (herbicide) in application doses from 1.5 to $12 \mathrm{~mm}^{3} \mathrm{~kg}^{-1}$ and reported its negative impact not only on the activity of dehydrogenases and urease but also on acid and alkaline phosphatases. Yao et al. (2006) demonstrated that acetamipiryd (insecticide) did not have a significant impact on the activity of catalase and urease but inhibited the activity of phosphatases. Walia et al. (2014) treated soil with mancozeb in doses from 10 to $2000 \mathrm{mg} \mathrm{kg}^{-1}$ and observed the destructive activity of this fungicide on the activity of phosphatases, amylase and invertase. Baćmaga et al. (2012) tested the effects of carfentrazone-ethyl (herbicide) on dehydrogenases, acid phosphatase and alkaline phosphatase and found no changes in their activity levels. Regardless of the dose, the lowest activity of catalase, urease, acid phosphatase and alkaline phosphatase was observed on day 90 and of dehydrogenases on day 30 .

Determination of the soil resistance index and soil resilience index helps to identify whether or not a particular ecosystem exposed to various stressors can remain stable and maintain appropriate balance (Griffiths and Philippot 2013; Orwin and Wardle 2004; Orwin and Wardle 2005; Orwin et al. 2006). In our study, the resistance of soil enzymes depended both on the dose of azoxystrobin and soil incubation time (Table 6). Treatment of soil with higher doses of the tested fungicide reduced RS values for all the analysed enzymes. However, urease was found most susceptible to the fungicide, particularly on day 60 , when the RS value decreased from 0.908 to 0.337 . In contrast to that, dehydrogenases showed the highest resistance to increased doses of azoxystrobin. Treatment of soil with a dose of 


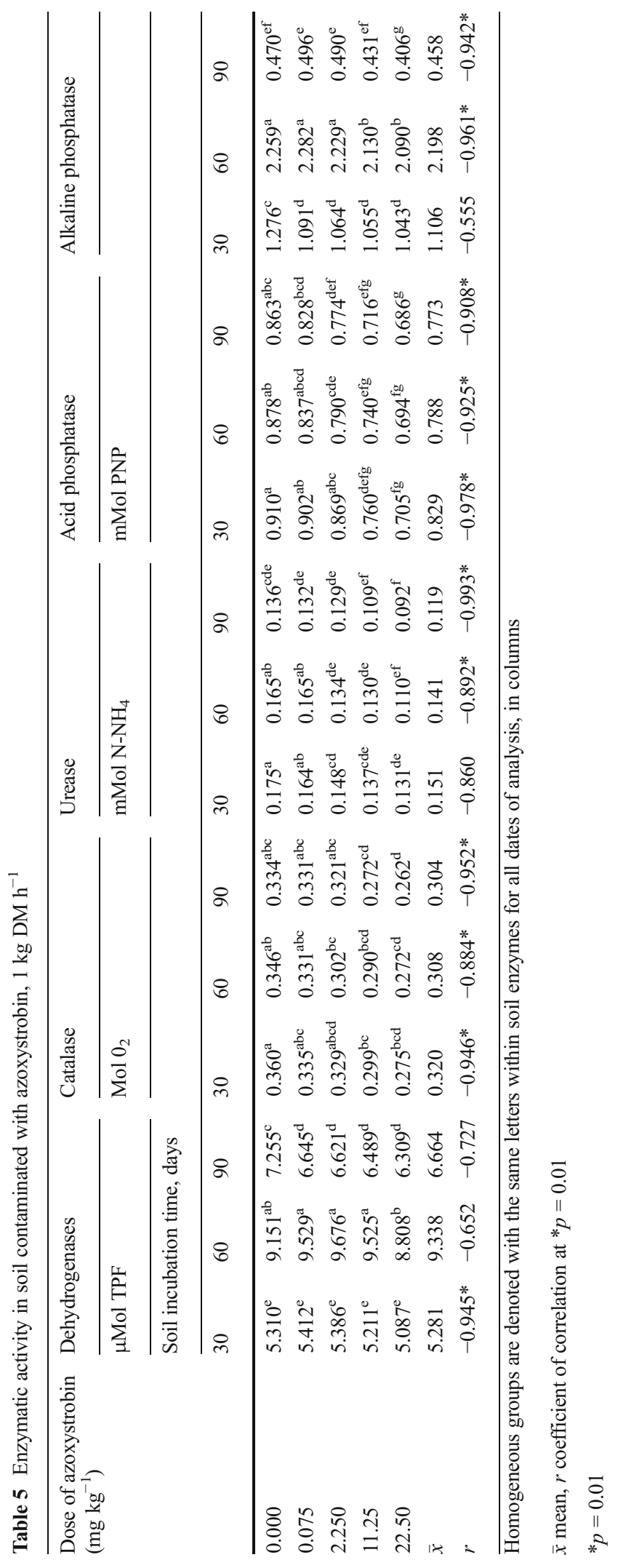


$2.25 \mathrm{mg} \mathrm{kg}^{-1}$ decreased the RS value on day 60 from 0.925 to 0.898 . In terms of resistance to the tested fungicide, enzymes were categorized in the following order: dehydrogenases $(0.874)>$ alkaline phosphatase $(0.810)>$ acid phosphatase $(0.746)>$ catalase $(0.718)>$ urease (0.646). Tomkiel et al. (2014) also noticed that urease was the most susceptible to the effects of a mixture containing two herbicidespethoxamid and terbuthylazine. Baćmaga et al. (2015) analysed the effects of soil treatment with a mixture of different herbicides (diflufenican + mesosulfuronmethyl + iodosulfuron methyl-sodium) on the enzymatic activity of soil and found the greatest resistance for urease and the lowest resistance for dehydrogenases. In another study, Be'caerta et al. (2006) tested 2,4-D and found that $\beta$-glucosidase and arylsulfatase were most susceptible to soil contamination with this herbicide. Baćmaga et al. (2014a), in an experiment with three herbicides (Fuego 500 SC, Alister Grande 190 OD and Lumax 537.5 SE), observed that $\beta$-glucosidase, followed by arylsulfatase, were the most resistant to Alister Grande 190 OD. The resistance (RS) of soil enzymes to contamination with azoxystrobin revealed by PCA is presented in Fig. 4. The first two principal components accounted for $93.78 \%$ of the total variance. Around the

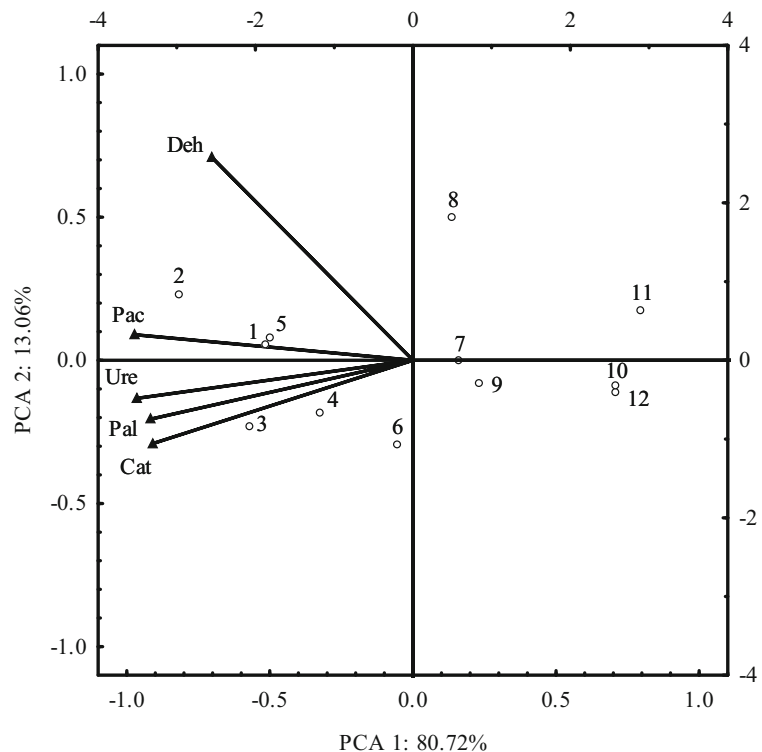

Fig. 4 Resistance of soil enzymes to contamination with azoxystrobin, determined by PCA. Explanation: vectors represent the primary variable: Deh dehydrogenases, Cat catalase, Ure urease, $\mathrm{Pac}$ acid phosphatase, $\mathrm{Pal}$ alkaline phosphatase; cases: $1-3\left(0.075 \mathrm{mg} \mathrm{kg}^{-1}\right)$; 4-6 (2.250 $\left.\mathrm{mg} \mathrm{kg}^{-1}\right) ; 7-9$ $\left(11.25 \mathrm{mg} \mathrm{kg}^{-1}\right) ; 10-12\left(22.50 \mathrm{mg} \mathrm{kg}^{-1}\right)$ 
first principal component, a homogeneous cluster was formed, including catalase, urease, acid phosphatase and alkaline phosphatase. There was a negative correlation between this variable and the resistance of the enzymes and a positive correlation between the resistance of enzymes. Dehydrogenases were positively correlated with the second principal component and negatively with the first component. The position of vectors in four quadrants of the coordinate system indicates different effects of azoxystrobin on the resistance of soil enzymes. As shown in the figure, the resistance of all the analysed enzymes depended on the level of soil contamination with this fungicide. The lowest resistance was found for enzymes in soil treated with azoxystrobin at doses of $11.25 \mathrm{mg} \mathrm{kg}^{-1}$ and $22.50 \mathrm{mg} \mathrm{kg}^{-1}$. Azoxystrobin contributed to long-term changes in the analysed soil (Table 7). In some samples, the soil resilience (RL) index was negative, reflecting the progressingly harmful effects of fungicide on soil biology during the experimental period. RL values ranged between -0.866 and 0.374 . Mean values of this index indicated that the balance was recovered in the longest time by catalase $(\mathrm{RL}=-0.689)$ and in the shortest time by alkaline phosphatase $(R L=0.296)$. The positive values of the RL index demonstrated the ability of soil to mitigate the stressful effects of pesticides. Baćmaga et al. (2014a), in an experiment with three herbicides (Fuego 500 SC, Alister Grande 190 OD and Lumax $537.5 \mathrm{SE}$ ), observed that longer time was required for arylsulfatase to recover balance than for $\beta$-glucosidase. However, the strongest negative effect on the value of the RL index was produced by Fuego 500 SC, containing metazachlor. Tomkiel et al. (2014) studied the effects of Successor T 550 SE (herbicide) and demonstrated the shortest recovery time for urease and the longest for arylsulfatase.

Identification of DNA from bacteria and fungi

Microorganisms play a key role in the biodegradation of pesticides and other chemicals in the soil ecosystem. Therefore, the use of pesticides requires an understanding of their effects on soil-dwelling microorganisms and the potential consequences of their inappropriate application. The application of high doses of pesticides in microbiological experiments allows for the identification of microbial strains with a high degradation potential and those useful for the bioremediation of soils contaminated with these substances (Chen et al. 2011; Jezierska-Tys and Rutkowska 2013). In this study, four bacterial strains of Bacillus spp. and two fungal strains of Aphanoascus spp. (Table 8) potentially able to degrade azoxystrobin used at a dose of $22.50 \mathrm{mg} \mathrm{kg}^{-1} \mathrm{DM}$ were isolated from soil. Azoxystrobin is one of the most important strobilurin-derived fungicides used on a large scale to protect plants against fungal pathogens. The isolated bacterial strains were identified as Bacillus cereus (KC848897.1), Bacillus weihenstephanensis (KF831381.1), Bacillus sp. (LM655314.1) and Bacillus megaterium (KJ843149.1). Cycoń et al. (2011) analysed soil contaminated with methyl thiophanate and isolated two bacterial strains, TDS and TDS-1, classified to the genera Enterobacter and Bacillus. In another study, Chennappa et al. (2014) concluded that Azotobacter spp. bacteria are able to degrade pesticides. The researchers demonstrated that 13 out of 14 isolated strains were able to grow on culture media containing herbicides (pendimethalin and

Table 7 Resilience index (RL) of soil contaminated with azoxystrobin on day 90 of the experiment

\begin{tabular}{|c|c|c|c|c|c|}
\hline $\begin{array}{l}\text { Dose of azoxystrobin } \\
\left(\mathrm{mg} \mathrm{kg}^{-1}\right)\end{array}$ & Dehydrogenases & Catalase & Urease & Acid phosphatase & Alkaline phosphatase \\
\hline 0.075 & -0.467 & -0.818 & -0.491 & -0.786 & 0.235 \\
\hline 2.250 & -0.467 & -0.866 & -0.468 & -0.647 & 0.243 \\
\hline 11.25 & -0.508 & -0.624 & -0.225 & -0.536 & 0.330 \\
\hline 22.50 & -0.551 & -0.449 & -0.062 & -0.485 & 0.374 \\
\hline $\bar{x}$ & -0.498 & -0.689 & -0.312 & -0.614 & 0.296 \\
\hline$r$ & $-0.996^{*}$ & $0.979 *$ & $0.991 *$ & 0.902 & $0.982 *$ \\
\hline
\end{tabular}

$\bar{x}$ mean, $r$ coefficient of correlation at $* p=0.01$

$* p=0.01$ 
Table 8 Identification of bacteria (based on the 16S rRNA gene sequence) and fungi (based on the ITS region sequence) isolated from soil

\begin{tabular}{|c|c|c|c|c|}
\hline \multirow{2}{*}{$\begin{array}{l}\text { Dose of azoxystrobin } \\
m g \mathrm{~kg}^{-1}\end{array}$} & \multirow[t]{2}{*}{ Strain number } & \multicolumn{3}{|l|}{ Homology to } \\
\hline & & Species & Strain & $\%$ \\
\hline \multicolumn{5}{|l|}{ Bacteria } \\
\hline \multirow[t]{4}{*}{0.00} & B1 & Bacillus anthracis & KF475884.1 & 99 \\
\hline & $\mathrm{B} 2$ & Bacillus cereus & KF010349.1 & 99 \\
\hline & B3 & Bacillus sp. & JN872500.1 & 100 \\
\hline & B4 & Bacillaceae bacterium & DQ490406.1 & 99 \\
\hline \multirow[t]{4}{*}{0.075} & B5 & Bacillus sp. & KM083527.1 & 100 \\
\hline & B6 & Bacillus sp. & KF956561.1 & 99 \\
\hline & B7 & Bacillus megaterium & KJ919967.1 & 100 \\
\hline & B8 & Bacillus simplex & GU969132.1 & 99 \\
\hline \multirow[t]{4}{*}{22.50} & B9 & Bacillus cereus & KC848897.1 & 99 \\
\hline & $\mathrm{B} 10$ & Bacillus weihenstephanensis & KF831381.1 & 99 \\
\hline & B11 & Bacillus sp. & LM655314.1 & 100 \\
\hline & B12 & Bacillus megaterium & KJ843149.1 & 100 \\
\hline \multicolumn{5}{|l|}{ Fungi } \\
\hline \multirow[t]{4}{*}{0.00} & G1 & Acremonium cellulolyticus & KF811039.1 & 100 \\
\hline & $\mathrm{G} 2$ & Talaromyces pinophilus & KF751644.1 & 100 \\
\hline & G3 & Penicillium sp. & GU973745.1 & 99 \\
\hline & G4 & Trichoderma viride & GU048860.1 & 99 \\
\hline \multirow[t]{3}{*}{0.075} & G5 & Penicillium chrysogenum & KF039676.1 & 99 \\
\hline & G6 & Penicillium sp. & AB734793.1 & 99 \\
\hline & G7 & Acremonium cellulolyticus & GU479898.1 & 99 \\
\hline \multirow[t]{2}{*}{22.50} & G8 & Aphanoascus terreus & AB861677.1 & 99 \\
\hline & G9 & Aphanoascus fulvescens & JN943451.1 & 99 \\
\hline
\end{tabular}

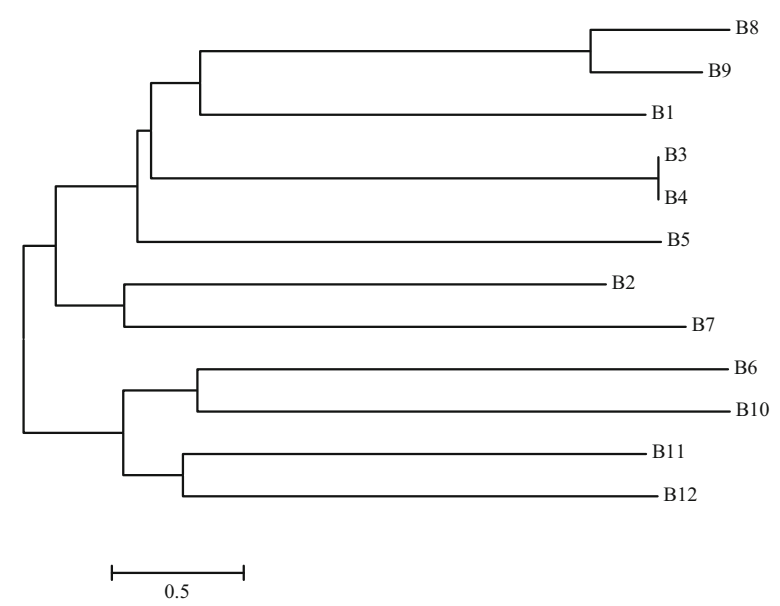

Fig. 5 A phylogenetic tree of bacterial strains isolated from soil, prepared based on the comparison of the 16S rRNA gene sequence. Explanation: B1, Bacillus anthracis; B2, Bacillus cereus; B3, Bacillus sp.; B4, Bacillaceae bacterium; B5, Bacillus sp.; B6, Bacillus sp.; B7, Bacillus megaterium; B8 Bacillus simplex; B9, Bacillus cereus; B10, Bacillus weihenstephanensis; B11, Bacillus sp.; B12, Bacillus megaterium

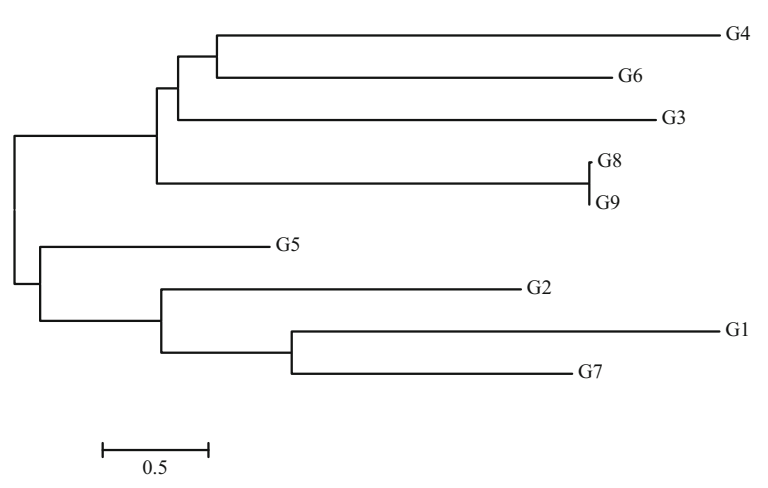

Fig. 6 A phylogenetic tree of fungal strains isolated from soil, prepared based on the comparison of the ITS region sequence. Explanation: G1, Acremonium cellulolyticus; G2, Talaromyces pinophilus; G3, Penicillium sp.; G4, Trichoderma viride; G5, Penicillium chrysogenum; G6, Penicillium sp.; G7, Acremonium cellulolyticus; G8, Aphanoascus terreus; G9, Aphanoascus fulvescens 
glyphosate) and insecticides (chlorpyrifos and phorate). Ahemad and Khan (2011) tested tebuconazole (fungicide) in doses of 100, 200 and $300 \mathrm{mg} \mathrm{kg}^{-1}$ and isolated Rhizobium strain MRP1. They also observed that the treatment of soil contaminated with tebuconazole increased pea production. Studies by Zhang et al. (2012) demonstrated that certain microbial species, such as Rhodobacter sphaeroides W16 and Acinetobacter lwoffii DNS32 isolates, may be useful in the bioremediation of soils contaminated with atrazine (herbicide). Researchers also concluded that atrazine produced a greater inhibition of growth in Bacillus subtilis B19. To date, there have been no available reports on azoxystrobin-degrading fungal strains. Therefore, our study was aimed at isolating fungi able to degrade this fungicide. Based on DNA sequencing of the ITS region, two strains, Aphanoascus terreus (AB861677.1) and Aphanoascus fulvescens (JN943451.1), were isolated from sandy clay loam contaminated with azoxystrobin at a dose of $22.500 \mathrm{mg} \mathrm{kg}^{-1}$.

A phylogenetic tree representing the linkage distance between the analysed bacterial strains (Fig. 5) prepared based on the analysis of the 16S rRNA gene sequence indicated three groups with a high level of similarity. The first group comprised two more or less strongly related sub-groups, i.e. B11 and B12 strains in the first sub-group, and B6 and B10 strains in the second one. The genetic distance between these strains was 1.8 and $2.0 \%$, respectively. The second group comprised B2 and B7 strains (genetic distance $2.1 \%$ ). The third group comprised four sub-groups: B5 strain in the first, B3 and $\mathrm{B} 4$ in the second, $\mathrm{B} 1$ in the third, and $\mathrm{B} 8$ and $\mathrm{B} 9$ in the fourth.

The phylogenetic tree for fungi obtained based on the analysis of nucleotide sequences from the ITS region is presented in Fig. 6. Fungi isolated from soil were classified to the genera Trichoderma, Penicillium, Aphanoascus, Talaromyces and Acremonium. The G1 isolate had $100 \%$ and G7 $99 \%$ similarity with the nucleotide sequence of Acremonium cellulolyticus. Other isolated strains had very high levels of similarity (99 \%) with other species: G2 with Talaromyces pinophilus, G3 and G6 with Penicillium sp., G4 with Trichoderma viride, G5 with Penicillium chrysogenum, G8 with Aphanoascus terreus and G9 with Aphanoascus fulvescens. A dendrogram indicated two major groups of genetically related fungi, i.e. G1, G2, G5 and G7 strains in the first group, and G3, G4, G6, G8 and G9 strains in the second group.

\section{Conclusions}

Azoxystrobin has a harmful effect on soil microorganisms and their biodiversity, as well as enzymatic activity and resistance of soil. The microbial and biochemical soil indices identified in the study provided necessary information about soil quality and fertility. The calculated predicted environmental concentration (PEC) of azoxystrobin in soil confirms the fact that the use of this fungicide in contaminating doses creates a risk to living organisms. These findings suggest that azoxystrobin designed for the control of fungal diseases in crops and vegetables should be used carefully and according to the manufacturer's recommendations. Its use in increased doses distorts the homeostasis of soil determined based on the activity of soil microorganisms, which can have a strong impact on plant growth and yield. Bacterial and fungal strains isolated from soil show the adaptability to contamination of soil with azoxystrobin but also with other strobilurin-derived substances. Because of their degrading potential, these microorganisms can be considered when developing strategies for the bioremediation of soils contaminated with pesticides.

Open Access This article is distributed under the terms of the Creative Commons Attribution 4.0 International License (http:// creativecommons.org/licenses/by/4.0/), which permits unrestricted use, distribution, and reproduction in any medium, provided you give appropriate credit to the original author(s) and the source, provide a link to the Creative Commons license, and indicate if changes were made.

\section{References}

Ahemad, M., \& Khan, M. S. (2011). Effect of tebuconazoletolerant and plant growth promoting Rhizobium isolate MRP1 on pea-Rhizobium symbiosis. Scientia Horticulturae, 129, 266-272.

Alef, K., \& Nannipieri, P. (1998). Methods in applied soil microbiology and biochemistry. In K. Alef, \& P. Nannipieri (Eds.), Academic Press, Harcourt Brace \& Company (pp. pp. 316pp. 365). London: Publishers.

Alef, K., Nannipieri, P., \& Trazar-Capeda, C. (1998). Phosphatase activity in: methods in applied soil microbiology and biochemistry. In K. Alef, \& P. Nannipieri (Eds.), Academic Press Harcourt Brace \& Company (pp. pp. 335-pp. 344). London: Publishers.

Alexander, M. (1973). Microorganisms and chemical pollution. Bioscience, 23, 509-515. 
Araújo, A. S. F., Monteiro, R. T. R., \& Abarkeli, R. B. (2003). Effect of glyphosate on the microbial activity of two Brazilian soil. Chemosphere, 52, 799-804.

Baćmaga, M., Boros, E., Kucharski, J., \& Wyszkowska, J. (2012). Enzymatic activity in soil contaminated with the Aurora 40 WG herbicide. Environment Protection Engineering, 38(1), 91-102.

Baćmaga, M., Borowik, A., Kucharski, J., Tomkiel, M., \& Wyszkowska, J. (2015). Microbial and enzymatic activity of soil contaminated with a mixture of diflufenican + mesosulfuron-methyl + iodosulfuron-methyl-sodium. Environmental Science and Pollution Research, 22, 643656.

Baćmaga, M., Wyszkowska, J., Borowik, A., Tomkiel, M., \& Kucharski, J. (2014a). Response of fungi, $\beta$-glucosidase and arylsulfatase to soil contamination by Alister Grande 190 OD, Fuego 500 SC and Lumax 357.5 SE herbicides. Polish Journal of Environmental Studies, 23(1), 19-25.

Baćmaga, M., Kucharski, J., Wyszkowska, J., Borowik, A., \& Tomkiel, M. (2014b). Responses of microorganisms and enzymes to soil contamination with metazachlor. Environmental Earth Sciences, 72, 2251-2262.

Bartlett, D. W., Clough, J. M., Godwin, J. R., Hall, A. A., Hamer, M., \& Parr-Dobrzanski, B. (2002). The strobilurin fungicides. Pest Management Science, 58(7), 649-662.

Be'caert, V., Samson, R., Deschenes, L. (2006). Effect of 2,4-D contamination on soil functional stability evaluated using the relative soil stability index (RSSI). Chemosphere, 64, 17131721.

Bending, G.D., Rodr1'guez-Cruz, M.S., Lincoln S.D. (2007). Fungicide impacts on microbial communities in soils with contrasting management histories. Chemosphere, 69, 82-88.

BS EN ISO 11260. (2011). Soil quality. Determination of effective cation exchange capacity and base saturation level using barium chloride solution.

Carter, M.R. (1993). Soil sampling and methods of analysis. Canadian Society of Soil Science, Lewis Publishers, London.

Chatterjee, N. S., Gupta, S., \& Varghese, E. (2013). Degradation of metaflumizone in soil: impact of varying moisture, light, temperature, atmospheric $\mathrm{CO}_{2}$ level, soil type and soil sterilization. Chemosphere, 90, 729-736.

Chen, S., Yang, L., Hu, M., \& Liu, J. (2011). Biodegradation of fenvalerate and 3-phenoxybenzoic acid by a novel Stenotrophomonas sp. strain ZS-S-01 and its use in bioremediation of contaminated soils. Applied Microbiology and Biotechnology, 90, 755-767.

Chen, S. K., Edwards, C. A., \& Subler, S. (2001). Effects of the fungicides benomyl, captan and chlorothalonil on soil microbial activity and nitrogen dynamics in laboratory incubations. Soil Biology and Biochemistry, 33, 1971-1980.

Chennappa, G., Adkar-Purushothama, C. R., Suraj, U., Tamilvendan, K., \& Sreenivasa, M. Y. (2014). Pesticide tolerant Azotobacter isolated from paddy growing areas of northern Karnataka, India. World Journal of Microbiolology and Biotechnology, 30(1), 1-17.

Clinton, B., Warden, A. C., Haboury, S., Easton, C. J., Kotsonis, S., Taylor, M. C., Oakeshott, J. G., Russell, C., \& Scott, R. J. (2011). Bacterial degradation of strobilurin fungicides: a role for a promiscuous methyl esterase activity of the subtilisin proteases? Biocatalysis and Biotransformation, 29(4), 1-11.
Crouzet, O., Batisson, I., Besse-Hoggan, P., Bonnemoy, F., Bardot, C., Poly, F., Bohatier, J., \& Mallet, C. (2010). Response of soil microbial communities to the herbicide mesotrione: a dose-effect microcosm approach. Soil Biology and Biochemistry, 42, 193-202.

Cycoń, M., Wójcik, M., \& Piotrowska-Seget, Z. (2011). Biodegradation kinetics of the benzimidazole fungicide thiophanate-methyl by bacteria isolated from loamy sand soil. Biodegradation, 22, 573-583.

De Leij, F. A. A. M., Whipps, J. M., \& Lynch, J. M. (1993). The use of colony development for the characterization of bacterial communities in soil and on roots. Microbial Ecology, 27, 81-97.

Demenaou, J., Monkiedje, A., Nin, T., Foto, S. M., Nola, M., \& Kemka, N. (2004). Changes in soil chemical properties and microbial activity response to the fungicide Ridomil Gold plus copper. International Journal Environmental Research and Public Health, 1, 26-34.

Floch, C., Chevremont, A. C., Joanico, K., Capowiez, Y., \& Criquet, S. (2011). Indicators of pesticide contamination: soil enzyme compared to functional diversity of bacterial communities via biolog ecoplates. European Journal of Soil Biology, 47, 256-263.

Ghosh, R. K., \& Singh, N. (2009). Effect of organic manure on sorption and degradation of azoxystrobin in soil. Journal of Agricultural of Food Chemistry, 57(2), 632-636.

Griffiths, B. S., \& Philippot, L. (2013). Insights into the resistance and resilience of the soil microbial community. FEMS Microbiology Reviews, 37, 112-129.

Guo, P., Zhu, L., Wang, J., Wang, J., Xie, H., \& Lv, D. (2015). Enzymatic activities and microbial biomass in black soil as affected by azoxystrobin. Environmental Earth Sciences. doi: 10.1007/s12665-015-4126-z.

Jastrzębska, E., \& Kucharski, J. (2007). Dehydrogenases, urease and phosphatases activities of soil contaminated with fungicides. Plant, Soil and Environment, 53(2), 51-57.

Jezierska-Tys, S., \& Rutkowska, A. (2013). Soil response to chemicals used in a field experiment. International Agrophysics, 27(2), 151-158.

Katagi, T. (2006). Behaviour of pesticides in water-sediment systems. Reviews of Environmental Contamination and Toxicology, 187, 133-253.

Kucharski, J., Baćmaga, M., \& Wyszkowska, J. (2009). Effect of hericydes of the course of ammonification in soil. Journal of Elementology, 14(3), 477-487.

Kucharski, J., \& Wyszkowska, J. (2008). Biological properties of soil contaminated with the herbicide Apyros 75 WG. Journal of Elementology, 13(3), 357-371.

Martin, J. (1950). Use of acid, rose bengal, and streptomycin in the plate method for estimating soil fungi. Soil Science, 69, 215233.

Martinez, C. O., Silva, C. M. M. S., Fay, E. F., Maia, A. H. N., Abakerli, R. B., \& Durrant, L. R. (2008). Degradation of the herbicide sulfentrazone in a Brazilian typic hapludox soil. Soil Biology and Biochemistry, 40, 879-886.

Monkiedje, A., Ilori, M. O., \& Spiteller, M. (2002). Soil quality changes resulting from the application of the fungicides mefenoxam and metalaxyl to a sandy loam soil. Soil Biology and Biochemistry, 34, 1939-1948.

Nelson, D. W., \& Sommers, L. E. (1996). Total carbon, organic carbon, and organic matter [in:] method of soil analysis: 
chemical methods. In D. L. Sparks (Ed.), American Society of Agronomy (pp. pp. 1201-pp. 1229). WI: Madison.

Öhlinger, R. (1996). Dehydrogenase activity with the Substrate TTC in: methods in soil Biology. In F. Schinner, R. Öhlinger, E. Kandler, \& R. Margesin (Eds.), Verlag Berlin Heidelberg (pp. pp. 241-pp. 243). Springer.

Oliveira, C.A., Alves, V.M.C., Marriel, I.E., Gomes, E.A., Scotti, M.R., Carneiro, N.P., Guimaraes, C.T., Schaffert, R.E., Sa, N.M.H. (2009). Phosphate solubilizing microorganisms isolated from rhizosphere of maize cultivated in an oxisol of the Brazilian Cerrado biome. Soil Biology and Biochemistry, 41, 1782-1787.

Orwin, K. H., \& Wardle, D. A. (2004). New indices for quantifying the resistance and resilience of soil biota to exogenous disturbance. Soil Biology and Biochemistry, 36, 1907-1912.

Orwin, K. H., \& Wardle, D. A. (2005). Plant species composition effects on belowground properties and the resistance and resilience of the soil microflora to a drying disturbance. Plant and Soil, 278, 205-221.

Orwin, K. H., Wardle, D. A., \& Greenfield, G. (2006). Contextdependent changes in the resistance and resilience of soil microbes to an experimental disturbance for three primary plant chronosequences. Oikos, 112, 196-208.

Parkinson, D., Gray, F. R. G., \& Williams, S. T. (1971). Methods for studying the ecology of soil micro-organism. Blackweel Scientific Publication Oxford and Edinburgh, IBP Handbook, 19.

PB 29 ed.303.12.2012. (2012). Soil quality_determination of total nitrogen.

PB 33 ed.3 03.12.2012. (2012). Grain size distribution of soil particles (range $0.02-2000 \mu \mathrm{m}$ )-laser diffraction method.

Ratcliff, A. W., Busse, M. D., \& Shestak, C. J. (2006). Changes in microbial community structure following herbicide (glyphosate) addition to forest soils. Applied Soil Ecology, 34, 114-124.

Rodrigues, E. T., Lopes, I., \& Pardal, M. Â. (2013). Occurrence fate and effects of azoxystrobin in aquatic ecosystems: a review. Environment International, 53, 18-28.

Ros, M., Goberna, M., Moreno, J.L., Hernandez, T., Garcìa, C., Insam, H., Pascual, J.A. (2006). Molecular and physiological bacterial diversity of a semi-arid soil contaminated with different levels of formulated atrazine. Applied Soil Ecology, 34, 93-102.

Saha, S., Dutta, D., Karmakar, R., \& Prasad, R. D. (2012). Structure-toxicity relationship of chloroacetanilide herbicides. Relative impact on soil microorganism. Environmental Toxicology and Pharmacology, 34, 307-314.

Sarathchandra, S. U., Burch, G., \& Cox, N. R. (1997). Growth patterns of bacterial communities in the rhizoplane and rhizosphere of with clover (Trifolium repens L.) and perennial ryegrass (Lolium perenne L.) in long-term pasture. Applied Soil Ecology, 6, 293-299.

Sebiomo, A., Ogundero, W. V., \& Bankloe, S. A. (2011). Effect of four herbicides on microbial population, soil organic matter and dehydrogenase activity. African Journal of Biotechnology, 10, 770-778.
Seiber, J. N., \& Kleinschmidt, L. A. (2011). Contribution of pesticide residue chemistry to improving food and environmental safety: past and present accomplishments and future challenges. Journal of Agricultural of Food Chemistry, 59, 7536-7543.

Serrano, A., Tejada, M., Gallego, M., \& Gonzalez, J. L. (2009). Evaluation of soil biological activity after a diesel fuel spill. Science of the Total Environment, 407, 4056-4061.

Singh, D. K., \& Kumar, S. (2008). Nitrate reductase, arginine deaminase, urease and dehydrogenase activities in natural soil (ridges with forest) and in cotton soil after acetamipirid treatments. Chemosphere, 71, 412-418.

Singh, P., \& Goshal, N. (2010). Variation in total biological productivity and soil microbial biomass in rainfed agroecosystems: impact of application of herbicide and soil amendments. Agriculture, Ecosystems and Environment, 137, 241-250.

Statsoft, Inc , Statistica. (2011). Data Analysis Software System, version 10.0. <http://www.statsoft.com. > .

Sukul, P. (2006). Enzymatic activities and microbial biomass in soil as influenced by metaxyl residues. Soil Biology and Biochemistry, 38, 320-326.

Tomkiel, M., Wyszkowska, J., Kucharski, J., Baćmaga, M., \& Borowik, A. (2014). Response of microorganisms and enzymes to soil contamination with the herbicide Successor T 550 SE. Environment Protection Engineering, 40(4), 15-27.

Walia, A., Mehta, P., Guleria, S., Chauhan, A., Shirkot, C.K. (2014). Impact of fungicide mancozeb at different application rates on soil microbial populations, soil biological processes and enzyme activities in soil. The Scientific World Journal, $1-9$.

World Reference Base of Soil Resources. (2014). A framework for international classification, correlation and communication. World Soils Resources Raport. 103, FAO, Rome.

Wyszkowska, J. (2002). Effect of soil contamination with Treflan $480 \mathrm{EC}$ on biochemical properties of soil. Polish Journal and Environmental Studies, 11(1), 71-77.

Wyszkowska, J., \& Kucharski, J. (2004). Biochemical and physicochemical properties of soil contaminated with herbicide Triflurotox 250 EC. Polish Journal of Environmental Studies, 13(2), 223-231.

Yao, X., Min, H., Lii, Z., \& Yuan, H. (2006). Influence of acetamipirid on soil enzymatic activities and respiration. European Journal of Soil Biology, 42, 120-126.

Zhang, H. B., Luo, Y. M., Zhao, Q. G., Wong, M. H., \& Zhang, G. L. (2006). Residues of organochlorine pesticides in Hong Kong soils. Chemosphere, 63, 633-641.

Zhang, Y., Meng, D., Wang, Z., Guo, H., Wang, Y., Wang, X., \& Dong, X. (2012). Oxidative stress response in atrazinedegrading bacteria exposed to atrazine. Journal of Hazardous Materials., 229-230, 434-438.

Zhang, Q., Zhu, L., Wang, J., Xie, H., Wang, J., Wang, F., \& Sun, F. (2014). Effects of fomesafen on soil enzyme activity, microbial population, and bacterial community composition. Environmental Monitoring and Assessment, 186(5), 28012812. 